\title{
Bacterial Formulations in Induction of Resistance and Growth Promotion of Tomato Plants
}

\author{
José R. M. Campos Neto ${ }^{1,2}$, Rafael Ribeiro Chaves ${ }^{2}$, Diogo Herison Silva Sardinha ${ }^{1,2}$, \\ Luiz Gustavo de Lima $\mathrm{Melo}^{3} \&$ Antônia Alice Costa Rodrigues ${ }^{2}$ \\ ${ }^{1}$ Instituto Federal de Educação, Ciência e Tecnologia do Maranhão, Caxias, Maranhão, Brazil \\ ${ }^{2}$ Universidade Estadual do Maranhão, São Luís, Maranhão, Brazil \\ ${ }^{3}$ Verde Planta Ltda., São Luís, Maranhão, Brazil \\ Correspondence: José R. M. Campos Neto, Instituto Federal de Educação, Ciência e Tecnologia do Maranhão, \\ 65600-505, Caxias, Maranhão, Brazil. Tel: 55-98-991-050-418. E-mail: jose.campos@ifma.edu.br
}

$\begin{array}{lcc}\text { Received: June 30, } 2018 & \text { Accepted: July 31, } 2018 & \text { Online Published: September 15, } 2018 \\ \text { doi:10.5539/jas.v10n10p493 } & \text { URL: https://doi.org/10.5539/jas.v10n10p493 }\end{array}$

The research is financed by Fundação de Amparo à Pesquisa e Desenvolvimento Científico e Tecnológico do Estado do Maranhão (FAPEMA).

\begin{abstract}
The objective of this work was to evaluate the effectiveness of seed treatment with fresh suspensions and powder formulations with Bacillus methylotrophicus to promote plant growth and induction of resistance against fusarium wilt (Fusarium oxysporum f. sp. lycopersici) in tomato plants under greenhouse conditions, verifying the occurrence of morphological and biochemical changes in the evaluated plants. Powder formulations based on Cassava (Manihot esculenta), Arrowroot (Maranta arundinacea) and sodium alginate containing Bacillus, in addition to the commercial product Quartz ${ }^{\circledR}$, were used to microbiolize the tomato seeds of the cultivar Santa Cruz. The formulations promoted plant growth, with a seedling vigor index greater than $50 \%$ for all treatments containing B. mthylotrophicus, in addition to a significant increase in total dry matter. The treatments induced systemic resistance, controlling the fusarium wilt with a $75 \%$ reduction of the disease and activation of enzymes such as peroxidase and polyphenoloxidase, only $\beta$-1,3-glucanase presented less activity than controls (treatments without B. mthylotrophicus). Thus, the use of formulations containing Bacillus are efficient in promoting plant growth of tomato plants and in inducing resistance to the control of fusarium wilt.
\end{abstract}

Keywords: Bacillus methylotrophicus, biological control, Fusarium oxysporum, plant growth-promoting bacteria, enzymatic activation

\section{Introduction}

The tomato (Solanum lycopersicum L.) is important for the Brazilian economy (Carvalho, Kist, \& Treichel, 2016), being the second most cultivated vegetable in the country (Camargo Filho \& Oliveira 2012). The State of Maranhão is the sixth producing state in the Northeast, with just over 3,900 tonnes in 193 hectares of harvested area (IBGE, 2015).

Among the diseases that cause large losses in the tomato crop, we can highlight the fusarium wilt caused by the fungus Fusarium oxysporum f. sp. lycopersici Schlecht Snyder \& Hansen (Inami et al., 2014). This disease occurs in all Brazilian states, significantly damaging the crop, with premature death of plants or destruction of all plants.

In addition, there is an urgent need for worldwide acceptance of the use of biological agents for disease control, partly in response to public concern about the use of toxic chemical pesticides, sometimes in violation of existing legislation, as noted in the ANVISA (2016), but also for the control of diseases that can not or are partially managed by other control strategies.

The use of resistance elicitors has been successful in the control of tomato fusarium wilt, including biotic and abiotic products, as well as the use of non-virulent $F$. oxysporum f. sp. lycopersici isolates (Farag Hanaa et al., 2011; Król, Igielski, Pollmann, \& Kępczyńska, 2015; Szilagyi-Zecchin, Mógor, Ruaro, \& Röder, 2015). 
Plants initiate response to primary and secondary metabolites of various associated plant pathogens. The immediate response of plants to various pathogenic attacks should be considered. (Mason et al., 2016). Among the secondary metabolites, plant hormones play a dynamic role in plant development and adaptation against biotic stresses. Salicylic acids (SA) and jasmonic acid (JA) are especially involved in the mediation of stresses in plants (Tsuda \& Katagiri, 2010), as a defense against insects and diseases and plant regulation under limiting abiotic factors such as nutritional deficiency, drought and shading (Taiz, Zeiger, Møller, \& Murphy, 2017).

As promising alternatives, plant growth-promoting rhizobacteria (PGPR) have been reported s host protectors against fungal infections (Droby, Wisniewski, Macarisin, \& Wilson, 2009; Sotoyama, Akutsu, \& Nakajima, 2016; Boukerma, Benchabane, Charif, \& Khélifi, 2017). Bacillus methylotrophicus is a rhizosphere soil bacterium and considered a PGPR involved in phytostimulation and diseases suppression of agricultural crops (Chen et al., 2007; Jeukens et al., 2015). Further, it has been reported that PGPR can increase the activity of plant defense-related enzymes and increase gene expression (Kim et al., 2015; Shahzad et al., 2017). In addition, research also shows that PGPR has ample antifungal activity (Sotoyama et al., 2016).

Several bacteria in the genus of Bacillus are cited as plant growth promoters because they exert direct antibiotic action on several pathogens. Besides being relevant resistance inducing agents (Chithrashree et al., 2011; Paul \& Lade, 2014; Szilagyi-Zecchin et al., 2015; Agbodjato et al., 2016; Sotoyama et al., 2016; Shahzad et al., 2017), they are promoting activation of genes for defense and expression of PR-proteins (Loon, Rep, \& Pieterse, 2006; Solanki et al., 2012), such as $\beta-1,3$-glucanases, chitinases and peroxidases, which can act directly on the pathogen, or indirectly, by the induction of resistance in the host (Kim et al., 2015).

The objective of this study was to evaluate the efficacy of seed treatment with fresh suspensions and powder formulations of Bacillus methylotrophicus for promoting plant growth and induction of resistance against fusarium wilt (F. oxysporum f. sp. lycopersici) in plant tomato, under greenhouse conditions, and to verify if morphological and biochemical changes occurred in the plants evaluated.

\section{Material and Methods}

\subsection{Experimental Location and Treatment Arrangement}

The tests were performed at the Plant Pathology Laboratory and Greenhouse, located at the State University of Maranhão (UEMA) in Maranhão State, Brazil.

Powder formulations were prepared by aseptically mixing $400 \mathrm{~mL}$ of bacterial suspension $\left(10^{8} \mathrm{cfu} / \mathrm{mL}\right)$, with 1.0 $\mathrm{kg}$ of cassava powder (Manihot esculenta L.), arrowroot (Maranta arundinacea L.) and sodium alginate, separately. Two isolates of Bacillus methylotrophicus, B12 and B47, were used. The isolates are contributed by mycology collection "Dr. Gilson Soares da Silva" on MGSSB12 and MGSSB47 record. The powdered substrates were pre-sterilized in autoclave at $121^{\circ} \mathrm{C}$ for 20 minutes. The formulations were used after 30 days of BOD storage at a temperature of $25 \pm 2{ }^{\circ} \mathrm{C}$ and photoperiod of 12 hours under fluorescent white light.

The research considered as sources of variation: Suspensions of Bacillus B12 and B47 (SUS.B12 and SUS.B47), cassava powder + Bacillus B12 and B47 (MAN.B12 and MAN.B47), arrowroot powder + Bacillus B12 and B47 (ARA.B12 and ARA.B47), sodium alginate powder + Bacillus B12 and B47 (ALG.B12 and ALG.B47), QUARTZ $^{\mathbb{B}}$ (fungicide based on B. methylotrophicus); besides control treatments constituted by the application of cassava powder $+\mathrm{H}_{2} \mathrm{O}$ Distilled and Deionized-DD (MAN.CRT), arrowroot poder $+\mathrm{H}_{2} \mathrm{O}$ DD (ARA.CRT), sodium alginate powder $+\mathrm{H}_{2} \mathrm{O}$ DD (ALG.CRT) and just $\mathrm{H}_{2} \mathrm{O}$ DD (CONTROL). In addition, the presence and absence of the pathogen were added as the second level of source of variation in the induced resistance for control of fusarium wilt.

Two parallel experiments were installed, one in tubes for evaluation of plant growth promotion and another in vessels for evaluation of induced resistance for control of fusarium wilt.

The seeds of the cultivar Santa Cruz were microbiolized with suspension of B. methylotrophicus by immersion of the seeds in the liquid suspensions and mixtures in the powder formulations in the proportion of $20 \mathrm{~g} / \mathrm{kg}$ of seed. The microbiolized seeds were seeded in tubes for the growth promotion experiment and in trays for seedlings for the experiment of resistance induction and control of fusarium wilt.

\subsection{Bacterial Formulations as Plant Growth Promoters}

In the experiment to promote plant growth the seeds were sown and kept for 30 days in tubes with $6.5 \mathrm{~cm}$ of superior diameter, containing inert and sterile substrate (vermiculite), leaving one plant per tube. All plants were received two applications of foliar fertilization NPK 8-8-8 applied with costal sprayer to the point of leaf runoff. 
The experiment was a completely randomized design, consisting of 13 treatments with four replicates, 100 plants for each replicate. The percentage of germination was evaluated 14 days after sowing, characterized as the portion of germinated seeds presenting its two cotyledons visible above the substrate.

Growth parameters were evaluated at 30 days of cultivation, including: root length, shoot length, root dry mass, and shoot dry mass. The vigor index of seedlings was obtained using the formula described by Abdul-Baki and Anderson (1973): VI $=$ Length of seedlings $(\mathrm{cm}) \times$ germination percentage. The data were submitted to analysis of variance and their average compared by parametric statistical tests.

\subsection{Bacterial Formulations as Inductors of Resistance}

For the induced resistance experiment the seedlings were transplanted 15 days after sowing to $5.0 \mathrm{~L}$ pots containing autoclaved soil and bovine manure, in a ratio of 1:3, maintaining three plants pot $^{-1}$ corresponding to an experimental unit. The inoculation of $F$. oxysporum f. sp. lycopersici occurred 30 days after sowing by

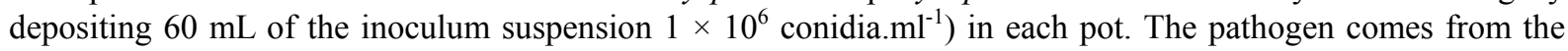
mycology collection "Professor Gilson Soares da Silva", on MGSS42 record.

The tomato plants were kept in a greenhouse until the end of the evaluations. The completely randomized design was used for the experiment resistance induced in disease control. A factorial arrangement was used: 13 (treatments) $\times 2$ (presence/absence of the pathogen $) \times 04$ replicates, each replicate represented by a pot containing three plants.

Leaf samples were collected 24, 48 and 240 hours after pathogen inoculation to evaluate the production of PR-proteins. The severity of the disease was evaluated at 21 days after inoculation using a rating scale: 1) Healthy plants; 2) Healthy plants, but with vascular necrosis; 3) Withered and chlorotic plants; 4) Withered plants with foliar necrosis; Necrotic or dead plants; these results expressed as percent disease control (Santos, 1999).

To determinethe PR-proteins an enzymatic extract was prepared after the collection of the vegetal material.

Briefly, $1.0 \mathrm{~g}$ samples of leaves that corresponded to each treatment were macerated in a mortar with liquid nitrogen and $1 \%(\mathrm{v} / \mathrm{v})$ polyvinylpyrrolidone (PVP), $5 \mathrm{~mL}$ of sodium acetate buffer $(0.1 \mathrm{M}, \mathrm{pH} 5)$ and $1 \mathrm{~mL}$ of EDTA $(1 \mathrm{mM})$. The extracts were centrifuged at $10,000 \mathrm{~g}$ for 10 minutes at $4{ }^{\circ} \mathrm{C}$, and the supernatants were transferred to $2-\mathrm{mL}$ eppendorf tubes and stored at $-80^{\circ} \mathrm{C}$. The enzyme extracts were used to determine the activities of peroxidases, polyphenol oxidases and $\beta-1,3$-glucanase.

The polyphenoloxidase activity-PPO (E.C. 1.10.3.1) was defined as the absorbance change at $410 \mathrm{~nm}$ and was calculated based on the molar extinction coefficient of $34 \mathrm{mM} \mathrm{cm}^{-1}$ for catechol and expressed as $\mu \mathrm{mol} \mathrm{g}^{-1} \mathrm{MF}$ $\min ^{-1}$.

The peroxidase activity-POD (E.C. 1.11.1.7) was defined as the absorbance change at $470 \mathrm{~nm}$ and was calculated based on the molar extinction coefficient of $26.6 \mathrm{mM} \mathrm{cm}^{-1}$ for guaicol, and expressed as $\mu \mathrm{mol} \mathrm{g} \mathrm{g}^{-1} \mathrm{MF}$ $\min ^{-1}$.

The $\beta$-1,3-glucanase determination (E.C. 3.2.1.29) was performed by the glucose dosage released by laminarin hydrolysis (Somogyi, 1952), with results expressed as $\mathrm{g}$ Glucose $\mathrm{g} \mathrm{FM}^{-1} \mathrm{~min}^{-1}$. The standard glucose curve was prepared in the same way as the samples, but laminarin was replaced with pre-established glucose concentrations (0 to $1,000 \mathrm{mg} \mathrm{L}^{-1}$ ). Finally, data were submitted to analysis of variance and their means compared by mean tests.

\section{Results}

\subsection{Bacterial Formulations as Plant Growth Promoters}

All treatments containing B. methylotrophicus showed increased plant growth, especially the length of the root system, where all the treatments differed from the controls (Figure 1). 




Figure 1. Shoot length and root system of tomato plants $(\mathrm{cm})$. VI: Seedling vigor index. Equal letters do not differ from each other by the Tukey test $(\mathrm{p}<0.05)$

We highlight the formulations based on cassava and arrowroot containing the native isolates B12 and B47: the treatments promoted a significant increase in plant growth, resembling the commercial product Quartz $^{\mathbb{B}}$.

Treatments based on sodium alginate did not differ from controls over shoot length. It was observed that the alginate produced a thick mucilage around the seeds, which may have delayed the emergence and/or development of the aerial part for these treatments.

There was no significant difference between treatment for germination rate, all of which had average of $94 \%$ higher germination. All treatments containing B. mthylotrophicus had a V.I. greater than $50 \%$. Control treatments containing only the formulations of cassava powder, arrowroot and sodium alginate showed similar V.I.'s statistically to each other, whereas the control with water only had the lowest values for all growth parameters evaluated.

The values of dry matter corroborate the growth patterns presented previously (Figure 2). All treatments containing B. methylotrophicus showed significant root, shoot and total dry mass values when compared to the control treatments, with the exception of sodium alginate treatments and suspension treatment of Bacillus B47, which resembled some controls, even differing from the absolute control, which contained only water. 


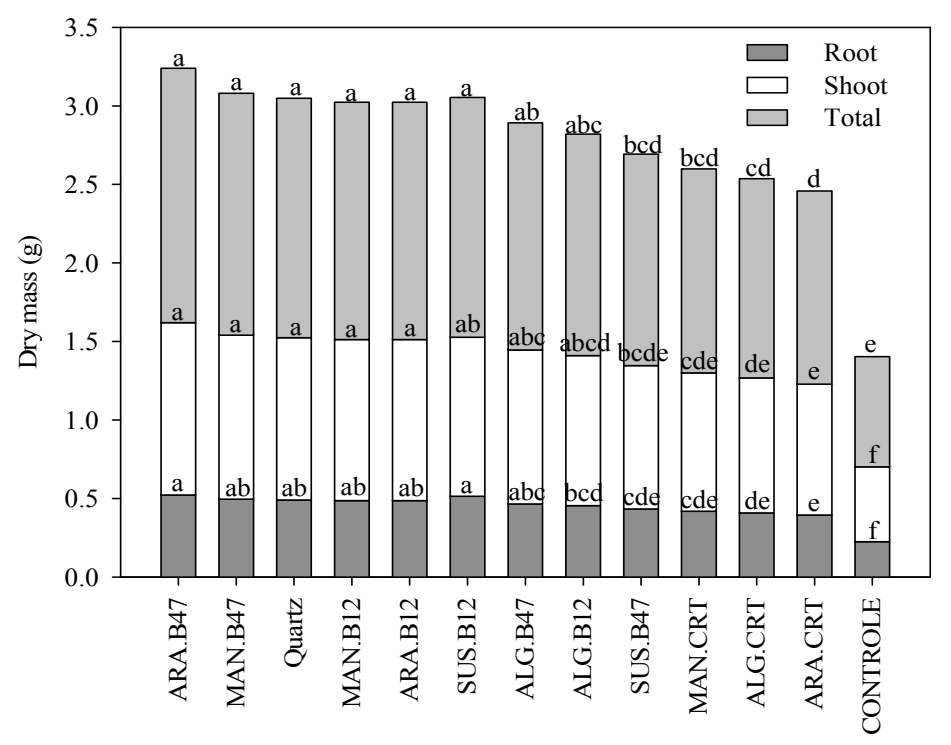

Figure 2. Root, shoot and total dry mass. Equal letters do not differ from each other by the Tukey test $(\mathrm{p}<0.05)$

\subsection{Bacterial Formulations as Inductors of Resistance}

Among the formulations tested, only Quartz ${ }^{\circledR}$ presented lower percetual control of fusarium wilt, controlling only $60 \%$ of the disease (Figure 3). The treatments containing B. methylotrophicus native from Maranhão presented a significant reduction in the disease, with absence of symptoms in the plants and inhibition of more than $70 \%$ of the disease, compared to the absolute control, which presented severe wilt associated with vascular dimming.

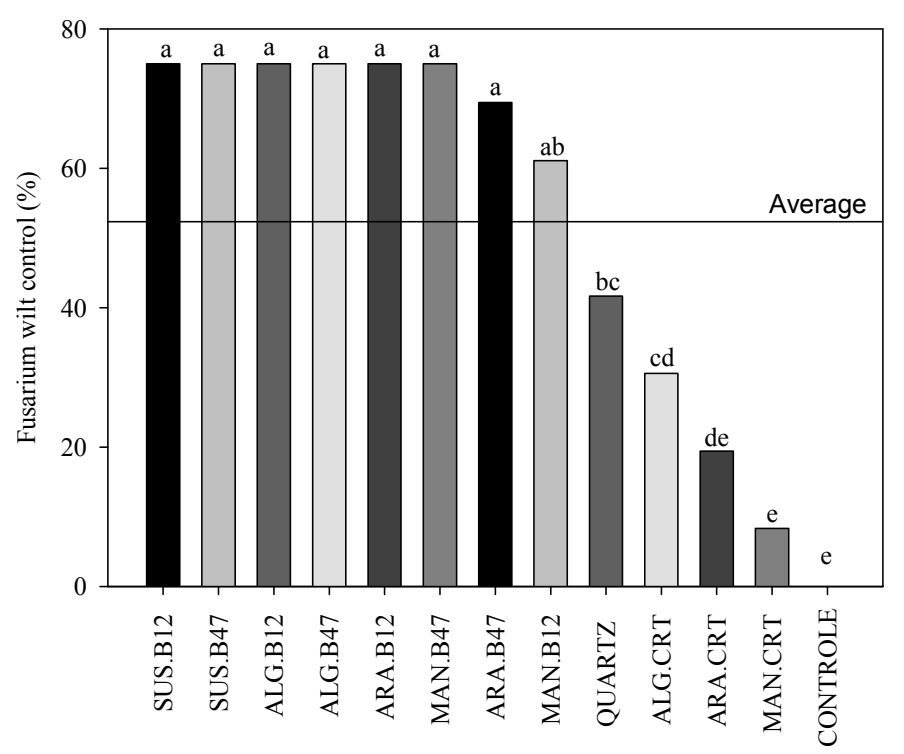

Figure 3. Control of fusarium wilt by application of formulations based on Bacillus methylotrophicus. Equal letters do not differ from each other by the Tukey test $(\mathrm{p}<0.05)$

We found a direct relationship between the action of the formulations tested on the expression of peroxidases and polyphenoloxidases activity and the disease control, indicating that these enzymes actively participated in the fight against the etiological agent fusarium wilt (Figure 4). 

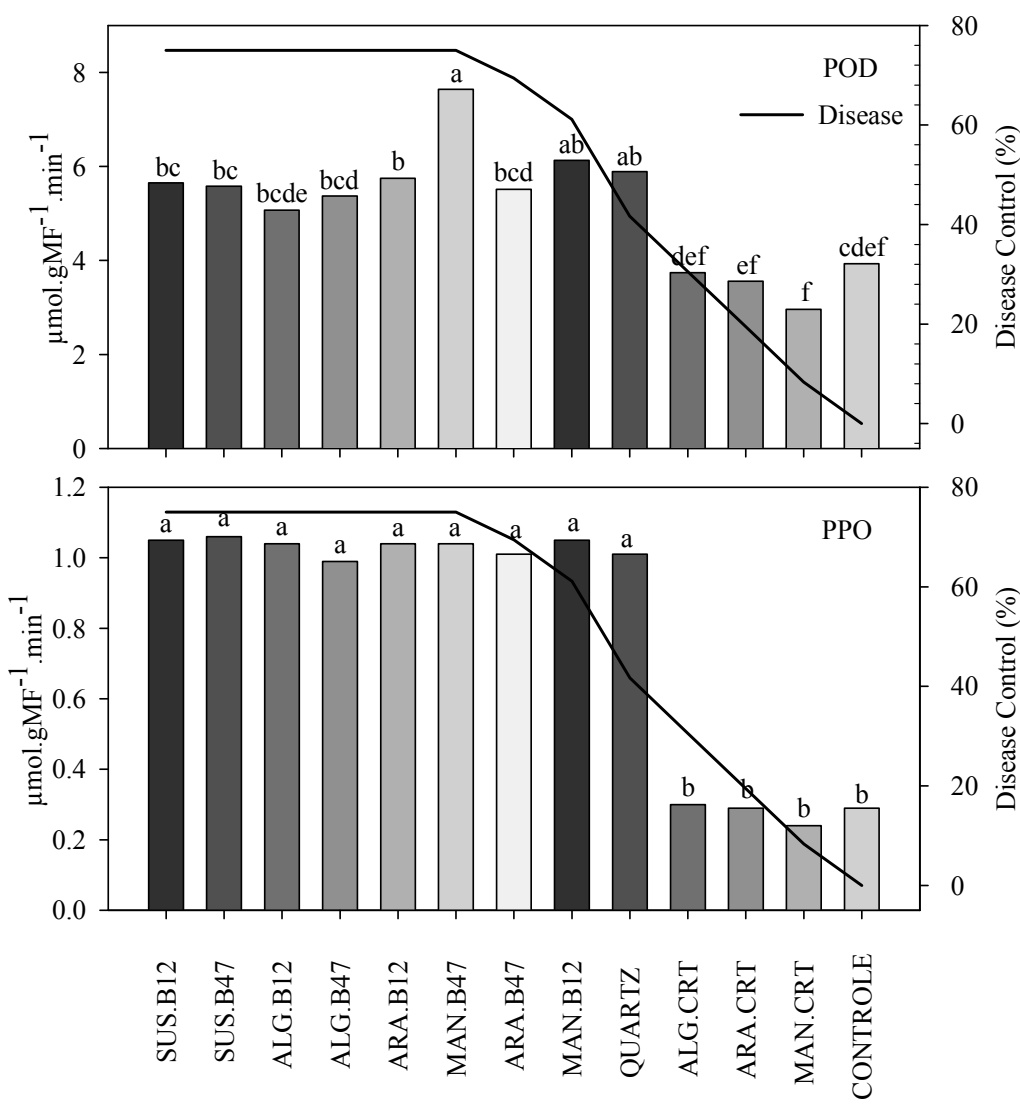

Figure 4. Effect of formulations on the activity of peroxides (POD) and polyphenoloxides (PPO), 240 hours after inoculation, in the control of fusarium wilt in tomato. Equal letters do not differ from each other by the Tukey test $(\mathrm{p}<0.05)$

The activities of peroxidase and polyphenoloxidase presented increasing values throughout the evaluations, differing significantly from the control treatments in each evaluation. The values of $\beta-1,3$-glucanase presented statistical difference, but only in the 240-hour sample, treatments ARA.B12 and ARA.B47 (arrowroot containing B. methylotrophicus) outperformed the control treatments (Figure 5). 


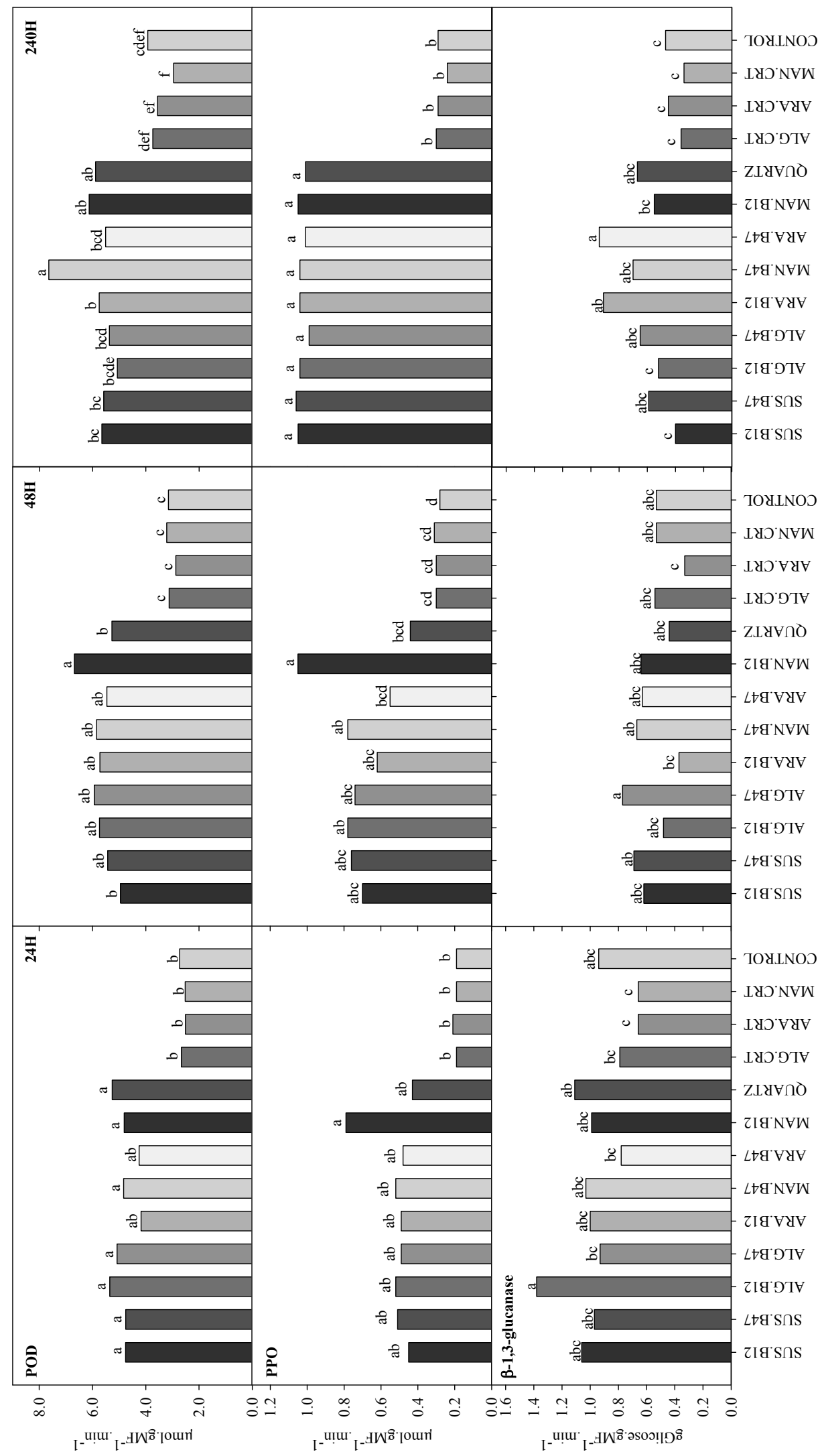

Figure 5. Activities of peroxidase (POD), polyphenoloxidase (PPO) and $\beta-1,3$-glucanase ( $\beta$-1,3) enzymes in tomato plants 25,48 and 240 hours after inoculation of $\mathrm{F}$. oxysporum $\mathrm{f}$. sp. lycopersici. Equal letters do not differ from each other by the Tukey test $(\mathrm{p}<0.05)$ 


\section{Discussion}

To proceed, growth promoting ability in tomato plants under greenhouse conditions was observed through the propagation of the bacteria by formulations tested. We highlight all the morphological variables tested (plant height, root length, vigor index, root and shoot dry matter and total dry matter) stimulating greater growth in tomato plants. These results reinforce the biological potential of the isolates tested, as well as their adaptability when stored in formulations of low economic and environmental cost.

Chowdappa, Mohan Kumar, Jyothi Lakshmi, and Upreti (2013) found promising results on tomato seeds inoculated with B. subtilis and Thichoderma harzianum with significant increase in all seedling growth parameters. The authors described root length, aerial part length, leaf area, fresh weight of shoots and roots increased by $38.53 \%, 32.04 \%, 62.68 \%, 28.87 \%$ and $36.21 \%$, respectively, in comparison with control seedlings.

It is clear that all treatments containing Bacillus promoted plant growth, especially the length of the root system, where all the treatments differed from the controls, indicating the potential this rhizobacterium in promoting good conditions for the development of the rhizosphere.

Formulations with combinations of beneficial bacterial strains that interact synergistically are in development and numerous research shows a promising trend in inoculation technology (Chithrashree et al., 2011; Sotoyama et al., 2016).

It is known that the materials used should not interfere with the bacterium-plant interaction to be considered minimally acceptable vehicles for agricultural practice, and also should provide ideal conditions for the proper development and storage of bacterial strains.

Furthermore, PGPR are excellent model systems that can provide biotechnology with new genetic constituents and bioactive chemicals with various uses in sustainable agriculture, providing control of diseases that can not or are partially managed by other control strategies.

Associated with an excellent germination rate for all seeds, the average Vigor Index value shows that all the plants treated with B. methylotrophicus had a rapid vegetative development, being superior to the control treatments (Tukey, $\mathrm{p}<0.05$ ), which gives them high survival capacity, vigor and stability of production.

The total accumulation of dry biomass promoted by native B. methylotrophicus treatments in cassava and arrowroot formulations represents a significant advance in the search for promising bioactive formulations, and linear data were found for size of plants (aerial part and root system) and vigor index value.

This notorious increase in plant growth coupled with biomass accumulation can be explained by the fact that several strains of Bacillus spp. and other PGPRs have the capacity to promote growth and increase in crop yield through increased absorption of nutrients stimulated by growth promotion factors such as expression of precursor genes of AIA and $\mathrm{GA}_{3}$, and decrease of ethylene level due to root colonization (Chen et al., 2007). Furthermore, it is believed that these hormones stimulate further absorption of nutrients in the soil, translate signals between plant organs and integrate them to produce appropriate defense responses to biotic or abiotic stress (Ghanashyam \& Jain, 2009).

These results were expected, since important metabolic changes were observed if we compared the significant differences between the activities of PR-proteins, confirming that there was activation of systemic resistance in the tomato cultivar Santa Cruz, with control of $F$. oxysporum f. sp. lycopersici by the application of formulations based on B. methylotrophicus.

Similar results were obtained by Sotoyama et al. (2016), who verified the control of $F$. oxysporum $\mathrm{f}$. sp. lycopersici with the application of $B$. amyloliquefaciens, evaluated by the application of real time-PCR for relative expression of several PR-proteins, such as acid glucanase, basic glucanase, acid chitinase and basic chitinase.

In addition, Endophytic bacteria promote plant growth and regulation of defense hormones, and can be used in the ecological control of F. oxysporum f. sp. lycopersici as suggested by Shahzad et al. (2017) when searching for B. amyloliquefaciens in tomato plants.

Araújo and Menezes (2009) observed a significant difference in the evaluation of peroxidase activity promoted by ASM, Azoxystrobin and Bacillus subtilis used as resistance elicitors in tomato plants. Similarly, Mandal, Mallick, and Mitra (2009) demonstrated that peroxidase activity showed a progressive increase in response to the application of salicylic acid, over 168 hours (7 days) in tomato plants.

It is known that high values of PR-proteins few hours after the pathogen application indicates that the plant activated or constituted sources of defense, a primordial characteristic of induced resistance described by several 
authors as a state of alert, where the plant responds with greater agility and efficiency when establishing the challenging pathogen.

For several authors, the application of resistance elicitors promotes activation of Acquired Systemic Resistance (ASR), causing a marked reduction in symptoms of the disease once it occurs initially in the region of infection, seeking to prevent or delay the penetration of the pathogen (Mei et al., 2014; Kim et al., 2015).

The data corroborate with the results found by Akram, Anjum, and Ali (2015), who evaluated the application of B. subtilis gainst tomato fusarium wilt and determined the concentration of enzymes such as phenylalanine ammonia lyase, polyphenoloxidase and peroxidase, with a significant increase in PPO and POD activities.

In contrast, these results differ from those found by Solanki et al. (2012), who found gene expression and amplification of $\beta$-1,3-glucanase in plants treated with Bacillus spp. against Rhizoctonia solani in tomato.

\section{Conclusions}

This study demonstrated that fresh suspensions and powder formulations of cassava, arrowroot and alginate containing B. methylotrophicus are efficient in promoting plant growth of tomato plants and resistance induced for the control of fusarium wilt under greenhouse conditions.

The seeds that are microbiolized with fresh suspensions and powdered formulations of cassava, arrowroot and alginate, containing $B$. methylotrophicus present greater development of biomass area and root, reaching higher levels of seedlings vigor and consequently quality in tillage. Furthermore, the application of B. methylotrophicus activates plant defense enzymes, increasing the activity of peroxidases and polyphenoloxidases in tomato plants, aid in the control of fusarium wilt, under greenhouse conditions, being equivalent to products already recommended, such as Quartz ${ }^{\circledR}$.

\section{Acknowledgements}

We thank the Fundação de Amparo à Pesquisa e Desenvolvimento Científico e Tecnológico do Estado do Maranhão (FAPEMA) for supporting this research.

\section{References}

Abdul-Baki, A. A., \& Anderson, J. D. (1973). Vigor Determination in Soybean Seed by Multiple Criterial. Crop Science, 13(6), 630-633. https://doi.org/10.2135/cropsci1973.0011183X001300060013x

Agbodjato, N. A., Noumavo, P. A., Adjanohoun, A., Agbessi, L., \& Baba-Moussa, L. (2016). Synergistic Effects of Plant Growth Promoting Rhizobacteria and Chitosan on In Vitro Seeds Germination, Greenhouse Growth, and Nutrient Uptake of Maize (Zea mays L.). Biotechnology Research International, 2016, 7830182. https://doi.org/10.1155/2016/7830182

Akram, W., Anjum, T., \& Ali, B. (2015). Searching ISR determinant/s from Bacillus subtilis IAGS174 against fusarium wilt of tomato. BioControl, 60(2), 271-280. https://doi.org/10.1007/s10526-014-9636-1

ANVISA. (2016). Activity Report 2013 to 2015. Program for analysis of pesticide residues in food-PARA (p. 246). Brasília: National Library.

Araújo, F. F., \& Menezes, D. (2009). Indução de resistência a doenças foliares em tomateiro por indutores biótico (Bacillus subtilis) e Abiótico (Acibenzolar-S-Metil). Summa Phytopathologic, 35(3), 169-172. https://doi.org/10.1590/S0100-54052009000300001

Boukerma, L., Benchabane, M., Charif, A., \& Khélifi, L. (2017). Activity of plant growth promoting rhizobacteria (PGPRs) in the biocontrol of tomato fusarium wilt. Plant Protection Science, 53(2), 78-84. https://doi.org/10.17221/178/2015-pps

Camargo Filho, W. P., \& Oliveira, A. C. (2012). Perfil da olericultura no Brasil e em São Paulo, 2011-junho/2012.

Carvalho, C. D., Kist, B. B., \& Treichel, M. (2016). Anuário brasileiro das hortaliças (p. 64). Santa Cruz do Sul: Editora Gazeta Santa Cruz.

Chen, X. H., Koumoutsi, A., Scholz, R., Eisenreich, A., Schneider, K., Heinemeyer, I., ... Borriss, R. (2007). Comparative analysis of the complete genome sequence of the plant growth-promoting bacterium Bacillus amyloliquefaciens FZB42. Nat Biotech, 25(9), 1007-1014. https://doi.org/10.1038/nbt1325

Chithrashree, Udayashankar, A. C., Chandra Nayaka, S., Reddy, M. S., \& Srinivas, C. (2011). Plant growth-promoting rhizobacteria mediate induced systemic resistance in rice against bacterial leaf blight 
caused by Xanthomonas oryzae pv. oryzae. Biological Control, 59(2), 114-122. https://doi.org/10.1016/ j.biocontrol.2011.06.010

Chowdappa, P., Mohan Kumar, S. P., Jyothi Lakshmi, M., \& Upreti, K. K. (2013). Growth stimulation and induction of systemic resistance in tomato against early and late blight by Bacillus subtilis OTPB1 or Trichoderma harzianum OTPB3. Biological Control, 65(1), 109-117. https://doi.org/10.1016/j.biocontrol. 2012.11.009

Droby, S., Wisniewski, M., Macarisin, D., \& Wilson, C. (2009). Twenty years of postharvest biocontrol research: Is it time for a new paradigm? Postharvest Biology and Technology, 52(2), 137-145. https://doi.org/10.1016/ j.postharvbio.2008.11.009

Farag Hanaa, R. M., Abdou, Z. A., Salama, D. A., Ibrahim, M. A. R., \& Sror, H. A. M. (2011). Effect of neem and willow aqueous extracts on fusarium wilt disease in tomato seedlings: Induction of antioxidant defensive enzymes. Annals of Agricultural Science, 56, 1-7. https://doi.org/10.1016/j.aoas.2011.05.007

Ghanashyam, C., \& Jain, M. (2009). Role of auxin-responsive genes in biotic stress responses. Plant Signaling \& Behavior, 4(9), 846-848. https://doi.org/10.4161/psb.4.9.9376

IBGE. (2015). Tomato: Productivity 2015. SIDRA.

Inami, K., Kashiwa, T., Kawabe, M., Onokubo-Okabe, A., Ishikawa, N., Pérez, E. R., ... Arie, T. (2014). The Tomato Wilt Fungus Fusarium oxysporum f. sp. lycopersici shares Common Ancestors with Nonpathogenic F. oxysporum isolated from Wild Tomatoes in the Peruvian Andes. Microbes and Environments, 29(2), 200-210. https://doi.org/10.1264/jsme2.ME13184

Jeukens, J., Kukavica-Ibrulj, I., Freschi, L., Jabaji, S., \& Levesque, R. C. (2015). Draft Genome Sequences of Two Lipopeptide-Producing Strains of Bacillus methylotrophicus. Genome Announcements, 3(5). https://doi.org/10.1128/genomeA.01176-15

Kim, J.-S., Lee, J., Lee, C.-H., Woo, S. Y., Kang, H., Seo, S.-G., \& Kim, S.-H. (2015). Activation of Pathogenesis-related Genes by the Rhizobacterium, Bacillus sp. JS, Which Induces Systemic Resistance in Tobacco Plants. The Plant Pathology Journal, 31(2), 195-201. https://doi.org/10.5423/ppj.nt.11.2014.0122

Król, P., Igielski, R., Pollmann, S., \& Kępczyńska, E. (2015). Priming of seeds with methyl jasmonate induced resistance to hemi-biotroph Fusarium oxysporum f.sp. lycopersici in tomato via 12-oxo-phytodienoic acid, salicylic acid, and flavonol accumulation. Journal of Plant Physiology, 179, 122-132. https://doi.org/ 10.1016/j.jplph.2015.01.018

Loon, L. C. V., Rep, M., \& Pieterse, C. M. J. (2006). Significance of Inducible Defense-related Proteins in Infected Plants. Annual Review of Phytopathology, 44(1), 135-162. https://doi.org/10.1146/annurev.phyto. 44.070505.143425

Mandal, S., Mallick, N., \& Mitra, A. (2009). Salicylic acid-induced resistance to Fusarium oxysporum f. sp. lycopersici in tomato. Plant Physiology and Biochemistry, 47, 642-649. https://doi.org/10.1016/j.plaphy. 2009.03.001

Mason, C. M., Bowsher, A. W., Crowell, B. L., Celoy, R. M., Tsai, C.-J., \& Donovan, L. A. (2016). Macroevolution of leaf defenses and secondary metabolites across the genus Helianthus. New Phytologist, 209(4), 1720-1733. https://doi.org/10.1111/nph.13749

Mei, L., Liang, Y., Zhang, L., Wang, Y., \& Guo, Y. (2014). Induced systemic resistance and growth promotion in tomato by an indole-3-acetic acid-producing strain of Paenibacillus polymyxa. Annals of Applied Biology, 165(2), 270-279. https://doi.org/10.1111/aab.12135

Paul, D., \& Lade, H. (2014). Plant-growth-promoting rhizobacteria to improve crop growth in saline soils: A review. Agronomy for Sustainable Development, 34(4), 737-752. https://doi.org/10.1007/s13593-0140233-6

Santos, J. R. M. (1999). Protocolo de Tecnologia: Seleção para resistência a doenças em hortaliças. N.3 Tomateiro/Murcha-de-fusario. EMBRAPA Hortaliças-Comunicado Técnico 11. EMBRAPA Hortaliças.

Shahzad, R., Khan, A. L., Bilal, S., Asaf, S., \& Lee, I.-J. (2017). Plant growth-promoting endophytic bacteria versus pathogenic infections: An example of Bacillus amyloliquefaciens RWL-1 and Fusarium oxysporum $\mathrm{f}$. sp. lycopersici in tomato. PeerJ, 5, e3107. https://doi.org/10.7717/peerj.3107

Solanki, M. K., Robert, A. S., Singh, R. K., Kumar, S., Pandey, A. K., Srivastava, A. K., \& Arora, D. K. (2012). Characterization of Mycolytic Enzymes of Bacillus Strains and Their Bio-Protection Role Against 
Rhizoctonia solani in Tomato. Current Microbiology, 65(3), 330-336. https://doi.org/10.1007/s00284-0120160-1

Somogyi, M. (1952). Notes on sugar determination. Journal of Biology and Biochermistry, 195, 19-23.

Sotoyama, K., Akutsu, K., \& Nakajima, M. (2016). Biological control of fusarium wilt by Bacillus amyloliquefaciens IUMC7 isolated from mushroom compost. Journal of General Plant Pathology, 82(2), 105-109. https://doi.org/10.1007/s10327-015-0641-8

Szilagyi-Zecchin, V. J., Mógor, Á. F., Ruaro, L., \& Röder, C. (2015). Crescimento de mudas de tomateiro (Solanum lycopersicum) estimulado pela bactéria Bacillus amyloliquefaciens subsp. plantarum FZB42 em cultura orgânica. Revista de Ciências Agrárias, 38, 26-33.

Taiz, L., Zeiger, E., Møller, I. M., \& Murphy, A. (2017). Fisiologia e desenvolvimento vegetal. Porto Alegre: Artmed.

Tsuda, K., \& Katagiri, F. (2010). Comparing signaling mechanisms engaged in pattern-triggered and effector-triggered immunity. Current Opinion in Plant Biology, 13(4), 459-465. https://doi.org/10.1016/ j.pbi.2010.04.006

\section{Copyrights}

Copyright for this article is retained by the author (s), with first publication rights granted to the journal.

This is an open-access article distributed under the terms and conditions of the Creative Commons Attribution license (http://creativecommons.org/licenses/by/4.0/). 